This is the authors' final version of the paper.

Original publication available at:

http://doi.org/10.1007/978-3-319-72923-7_33

Please cite as:

Femenia-Serra, F. (2018). Smart Tourism Destinations and Higher Tourism Education in Spain. Are We Ready for This New Management Approach? In B. Stangl \& J. Pesonen (Eds.), Information and Communication Technologies in Tourism 2018 (pp. 437-449). Cham: Springer.

\title{
Smart tourism destinations and higher tourism education in Spain. Are we ready for this new management approach?
}

\author{
Francisco Femenia-Serra \\ University Institute of Tourism Research \\ University of Alicante, Spain \\ paco.femenia@ua.es
}

\begin{abstract}
'Smart tourism' and 'smart tourism destinations' (STDs) have become commonplace in the research of the interrelationship between tourism, destinations and the latest Information and Communication Technologies (ICTs). However, research has failed hitherto to identify if this evolution towards smartness of tourism is accompanied by a similar process in tourism education to provide the system with prepared human resources once the transformation has been fully completed. This paper aims to fulfil this gap, by taking the case of Spanish public superior education in tourism, to analyse in which degree ICTs, as critical knowledge and skills required within STDs, are included in tourism curricula and how students assess the formation they receive in this regard. The analysis offers several valuable implications for governments in charge of public education design and opens discussion over the possibility to strengthen the technological side of tourism curricula.
\end{abstract}

Keywords: Smart tourism; Smart tourism destinations; ICTs; Tourism education

\section{Introduction}

Research on smart tourism has flourished as a novel approach to tackle some of the emerging realities in tourism due to the impact of the most recent ICTs over destinations, tourists and businesses (Koo, Park, \& Lee, 2017). Smart tourism however is still under construction, and it's deemed as a 'buzzword' being used without much consideration by multiple interested agents from a rather uncritical perspective (Gretzel, Reino, Kopera, \& Koo, 2015; Gretzel, Werthner, Koo, \& Lamsfus, 2015). Within research on this field, destinations have received most of the 
attention partly because of their parallelism to the successful smart city discourse (Boes, Buhalis, \& Inversini, 2016; Del Chiappa \& Baggio, 2015). This recent 'smart tourism destination' (STD) concept can be understood as a relevant contribution to the very concept of tourism destination (Jovicic, 2017), and even as a possible new framework to manage destinations (Ivars, Celdrán, Mazón, \& Perles, 2017) within the paradigm of smart tourism (Koo, Yoo, Lee, \& Zanker, 2016).

On one side, in the era of smart tourism it seems clear that ICTs have already provoked a tremendous transformation for tourism, and that this change has even been accelerated by the advent of smartphones, artificial intelligence, cloud computing or the Internet of Things (IoT) (Xiang \& Fesenmaier, 2017). These have open the possibility to generate great amounts of data and have given rise to a 'quantified traveller' (Choe \& Fesenmaier, 2017). On the other side, being tourism under a transition towards smartness, prepared human resources with considerable mastery of ICTs will be needed to manage this scenario from both a public and private perspective. However, while education in tourism has attracted great attention, with a clear emphasis on the need to find a balance between vocational and academic/theoretical requirements (Airey, Dredge, \& Gross, 2015), less focus has been put on the place ICTs have on the tourism curriculum (Munar \& Bødker, 2015). The specific skills and knowledge managers will need within smart destinations haven't been specified to date. Thus, apart from the need for identifying these, an important question arises in this context: Is current tourism education providing the needed theoretical foundations and practical skills for future smart tourism destinations managers?

As a result of this gap, this research intends to discern in which degree current superior tourism education is providing the required formation for this new approach to destinations management, by taking the case of Spain and the ICTs position in the country's tourism public education. Spain is argued to be an especially interesting case due to the strong institutional support to STD initiatives. In order to accomplish with the objective, first we discuss relevant literature on smart tourism destinations on one side, and tourism education and ICTs on the other side, which is followed in the second place by the explanation of the employed methods. In the third place the results, which are derived from a survey to both tourism graduate and postgraduate students and an exhaustive content analysis of the official tourism programmes in Spain, are presented. Finally, the results are framed within the broader discussion on smart tourism and tourism education, and the implications of the findings for education designers are highlighted.

\section{Theoretical background}

\subsection{Smart Tourism Destinations as a new destination management approach}

STDs are characterised by their ability to transform large amounts of data into enhanced tourist experiences and increased destination competitiveness thanks to the interconnection of the different stakeholders through latest ICT advancements, which would all together allow a better decision-making (Buhalis \& Amaranggana, 2014; X. Wang, Li, Zhen, \& Zhang, 2016). Their ability to collect and use massive data in order to deliver more personalised tourist experiences allows to understand and 
respond to tourists' needs in a real-time and context-aware manner (Choe \& Fesenmaier, 2017; Z. Xiang \& Fesenmaier, 2017). This aggregation and distribution to stakeholders of the data generated by tourists in their many interactions with different agents and elements within the system is dependent on the capacity of technologies such as IoT, end-user services and cloud computing combined with mobile technology and artificial intelligence (D. Wang, Li, \& Li, 2013; X. Wang et al., 2016). Hence, the STD proposes a new way of managing destinations based on the technological infrastructure and an intelligent decision-making. This way of 'running' a destination has attracted attention from governments around the world, within which Spain constitutes a remarkable example (SEGITTUR, 2015).

The smart destinations strategy was included in the Spanish National Plan for Tourism 2012-2015 (Ministerio de Industria, Energía y Turismo, 2013), and has been assigned to SEGITTUR (The national agency for fostering innovation and technologies in tourism). Nevertheless, STDs are a complex, multifaceted concept that encompasses diverse scopes such as sustainability, innovation and business opportunities creation or accessibility, as noted by SEGITTUR project. STDs are furthermore part of the global smart ecosystem depicted by Gretzel, Werthner et al. (2015), who also emphasise the need for a more critical approach towards the concept and its implications. According to these authors, smart tourism is characterised by the intricate relationship between their players (articulated through ICTs) and the common goal of providing better experiences. But smart tourism also represents a challenge for all stakeholders and their traditional roles, and it entails some risks which have been neglected hitherto. Despite this need to examine the concept and its holistic character critically, Spanish institutions have embraced this approach and continue fostering its spread among other decision-makers (local DMOs, businesses owners, etc.). The number of conferences, seminars, congresses and projects in the field is booming, although this is not accompanied for the moment by formal education. This would be on the other side hard to articulate as the concept itself and its applicability are still under construction (Del Chiappa \& Baggio, 2015; Gretzel, Sigala, Xiang, \& Koo, 2015). However, formation and training in several ICT-related fields can become useful frameworks to develop a consistent education for facing the advent of smartness in tourism. According to the just provided description literature makes of STDs functioning, some relevant knowledge and skills can be identified as crucial for their management: social media managing, big data analytics and database management, spatial analysis and visualisation tools, advanced web design or online marketing, seem to be relevant in this context apart from the more classical office software or transaction systems.

\subsection{Higher tourism education and ICTs}

Within academia, there is a growing debate around the curriculum design of tourism and/or hospitality and/or events programmes (also known as T\&H or TH\&E education) and the necessity to include different standpoints towards learning in them, which has crystallised in several initiatives. Among these, the 'Tourism Education Futures Initiative' (TEFI) advocates for adapting tourism education to a changing world in which new knowledge, values and skills are needed (Sheldon, Fesenmaier, Woeber, Cooper, \& Antonioli, 2008). 
In this changing world and tourism education context, ICTs marked a turning point and their influence over businesses operations and organisational performance was first seen as the capital reason to include them in tourism curriculum (Buhalis, 1998). Technologies in tourism education were progressively approached from an 'operational' point of view, understanding ICTs as a tool to enhance pedagogic methods and to adapt education to the needs of the informational society (Sigala \& Baum, 2003). This would be part of the 'e-Learning' concept, which is the technology-facilitated education and training and results especially appropriate for distant or mixed courses (Buhalis \& Law, 2008). E-Learning courses in tourism are provided by academia, corporate organisations, destination management organisations and independents (Cantoni, Kalbaska, \& Inversini, 2009).

Some monographies have been dedicated to education in tourism in the last years (e.g. Airey \& Tribe, 2005; Dredge, Airey, \& Gross, 2015b), in which technology is acknowledged as an influential driver of change. Nevertheless, as Munar \& Bødker (2015) argue, limited attention has been paid to the specific topic of curriculum design and ICTs. These authors stress the limited position of technologies in tourism curriculum, and how they are only taught from an operational, applied or technical perspective, focussing on management and business operations and leaving the critical approach aside, neglecting this way the wider implications IT has on tourism and societies. Hence, while ICTs have become commonplace in tourist experiences and decisions with the advent of smartphones (Wang, Park, \& Fesenmaier, 2012), the use of social media (Leung, Law, van Hoof, \& Buhalis, 2013), or more recently, smart technologies (Neuhofer, Buhalis, \& Ladkin, 2015), tourism education isn't providing students with knowledge and tools to understand and leverage this opportunity and think innovative (Munar \& Bødker, 2015).

A review of research regarding tourism students' perspective reveals that most works are devoted to gaining knowledge around their expectation in developing a career in tourism and hospitality (e.g. Barron, Maxwell, Broadbridge, \& Ogden, 2007; Jiang \& Tribe, 2009; Richardson, 2009; Richardson \& Thomas, 2012). However, few efforts have been dedicated to analysing their opinion on their education or their perception of the degree of adequacy of their curriculum for the future tourism situation and career opportunities. A good exception is the study by Benckendorff \& Moscardo (2015), who performed an interesting importance-performance analysis (IPA).

This issue is framed in the broader ongoing debate about the divide between liberal and vocational education, which can and should co-exist (Dredge et al., 2012). Therefore, education in tourism has to pursue a delicate equilibrium between the vocational/technical and liberal/academic sides of formation (Tribe, 2002). In finding this balance, curriculum designers are failing to include the vision of students regarding the most important trends on the tourism and their assessment of their ongoing formation adequacy to the identified challenges. This takes a further relevance in the era of smartness, where technology has come to play a critical role and education seems to be losing track. Spain constitutes a good example of this phenomenon. 


\subsection{ICTs in tourism higher education in Spain}

Tourism education in Spain has been traditionally separated from the university spectrum, and it was only in 1996 when the first official three years degree was introduced in public universities (Vera \& Ivars, 2001). According to these authors, in this moment much of formative offer was already being provided by private agents and greatly divided because of the educational competencies belonging to autonomous regions, with different type of regulation.

Regarding the inclusion of formation on ICTs in these recently established educational programmes, three studies have provided evidences on this matter in Spain over the last years. In Majó's (2004) analysis, the inclusion of 'informatics' or 'ICTs' in the curriculum was already deemed as deficient, with $67 \%$ of the universities teaching the degree in tourism including only one compulsory subject related to this field, and $6 \%$ including two subjects. Some years later, Medina \& González (2010) presented in their study how the companies in which students developed their practicum also noticed a need for a better formation in some technological tools. In a more recent study of Morais, Cunha, \& Gomes (2013) for both Portugal and Spain, the authors emphasised how in Spain the majority of tourism programmes offered only 6 ECTS in ICT-related subjects (same as in Majó's), but in some cases no courses at all were dedicated to this matter, and only in very limited cases two or three courses were included in the programme. Apart from the contribution of these studies, no systematic analysis of curricula has been performed so far lately, ignoring possible new needs and adaptations to the current situation and the emergence of new realities pushed by technologies. Additionally, the opinion of the students regarding this fact has been systematically neglected.

\section{Methods}

This research acknowledges the multifaceted reality of smart destinations, but stresses the special relevance of ICTs for their management, examining this way if public education is preparing future tourism practitioners in ICTs adequately. With this aim, the followed methodology consists of a mixed one, explained as follows.

\subsection{Survey}

Based on the literature review on smart destinations and their management, requirements in the formation of managers of this future scenario were detected and included in a specific section within a broader survey devoted to analysing the behaviour as tourists of university tourism students. This part of the questionnaire asked students to assess their level of satisfaction regarding the received formation hitherto in several ICT-related scopes critical for smart destinations:

- Big data

- Social media management

- Marketing online

- Geographical Information Systems (GIS)

- Web management
- Informatics for business management

- Word processors

- Database management

- GDSs 
Students also ranked by importance the factors influencing tourism in the future according to their opinion. Moreover, one question gathered their awareness about the very existence of the concept 'smart destination', which was followed by a second open answer question for them to express which concepts they would relate to this STD, even if they weren't aware of its meaning. This questionnaire was distributed to four different public universities in Spain which were offering tourism programmes (specified in section 3.2.) and total of 407 valid responses were collected and analysed through the software Qualtrics (C).

\subsection{Content analysis}

A content analysis was performed to contrast the results of the questionnaire. In the first phase, in order to limit the research units, the selection criteria for the programmes to be examined were defined: $a$ ) official degrees in 'Tourism' or 'Tourism \& Business Administration' plus official masters in 'Tourism (or Tourism Destinations) Management and/or Planning', which are $b$ ) provided by Spanish public universities. Specific programmes dedicated to events were discarded together with programmes entitled with 'Hospitality', which in Spanish has a different meaning.

The primary information source was the census of the National Official Register of Universities, Centres and Degrees. Departing from this extensive list, the indicated criteria $(a, b)$ were employed and the official websites of the selected universities were accessed individually. Then the educative offer subpage was checked manually to find their meeting with criteria $a$.

Table 1. Selection process

\begin{tabular}{|l|c|}
\hline & $\boldsymbol{n}$ \\
\hline Spanish universities & 85 \\
\hline Spanish public universities & 50 \\
\hline Offering tourism programmes & 38 \\
$\quad$ Degree: & 38 \\
$\quad \begin{array}{l}\text { 'Tourism' } \\
\text { 'Tourism \& Business Administration' }\end{array}$ & 11 \\
Master: & 15 \\
\hline 'Tourism Management and/or Planning' & 59 \\
\hline Programmes with 1 or more ICT-related courses & 5 \\
\hline Programmes without any formation in ICTs & 1,08 \\
\hline Compulsory ICT courses by programme (mean) & 0,7 \\
\hline Optional ICT courses by programme (mean) & 1,78 \\
\hline Total offered ICT courses by programme (mean) & \\
\hline
\end{tabular}

In the second phase, the syllabus of each of these programmes was queried through keywords to detect the courses with any ICT and smartness related content. The selected keywords for the search are shown in Table 2. The keywords were grouped afterwards to develop categories. The definition of these categories followed the criteria defined by Holsti (1969) as cited by Dwyer, Gill, \& Seetaram (2012): they are exhaustive, mutually exclusive and independent. Categories are grounded in the review of the courses and observed patterns. The courses with at least one of the keywords (in Spanish, here translated in English) were classified into an excel file. These data were processed and the courses grouped according the defined categories 
(see table 2). The coding scheme was developed partially based on the previously detected formation requirements for STDs (bullet points in section 3.1.), but was broadened to include more possible aspects of formation related to technology that weren't evaluated in the first place. The codes were tested to check their reliability, adjust and refine them. When ambiguous or generalist terms appeared (e.g. 'system' or 'information'), the author reviewed the content of the specific course to discriminate if it was actually related to ICTs or smartness and classify it accordingly.

\section{Results}

\subsection{Students' assessment of formation in ICTs and awareness of smart tourism destinations}

Through an aggregation of the responses regarding their formation on ICTs in their programme, the results reveal a quite pessimistic scenario, with most of the students qualifying their formation in ICTs as 'very bad', 'bad' or 'fair', while only a $25 \%$ say it has been 'good' or 'very good'.

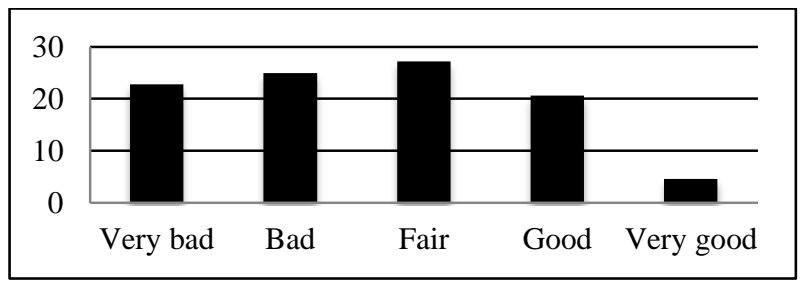

Fig. 1. Students' assessment of the received formation on ICTs (global, in \%)

Only when specific aspects of the formation on ICTs were examined by students, some slight differences emerged. These reveal students are more satisfied with their formation on the management of word processors and databases (mostly word and excel from Microsoft Office), together with online marketing.

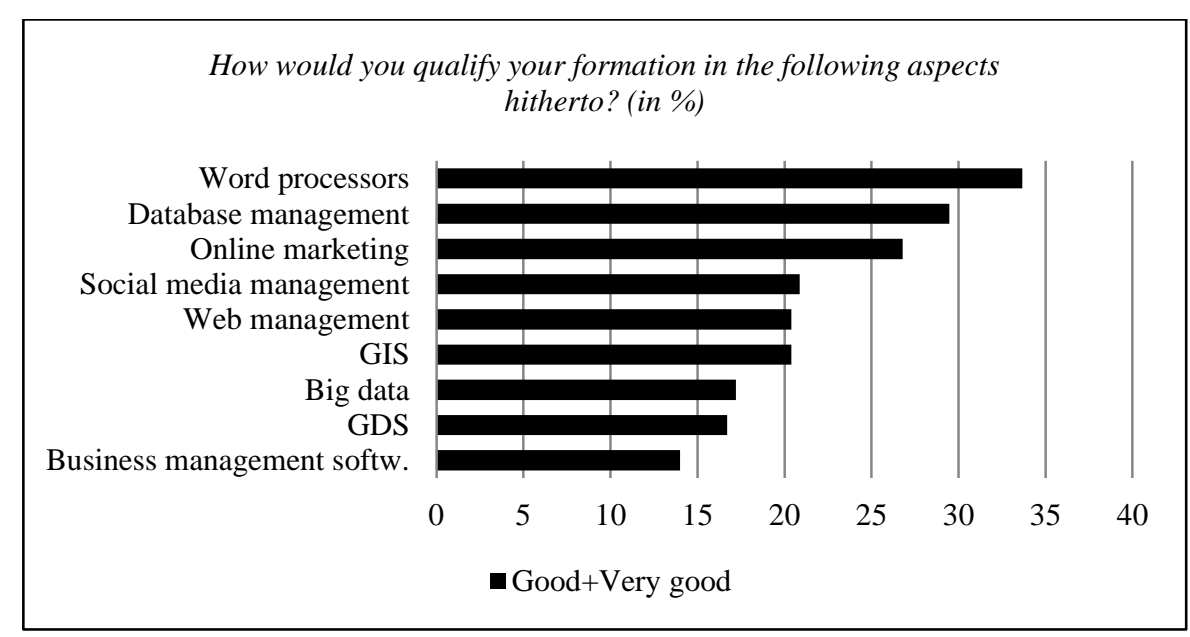

Fig. 2. Students' assessment of the received formation on specific ICT skills 
However, despite this poor perception of their undergoing formation on ICTs, the surveyed students are well-aware of the importance of ICTs and their impact on tourism. 'ICTs and the digital revolution' were ranked first in a list of nine factors which they evaluated according to their opinion on their future impact on tourism. Furthermore, there is a notable awareness among the tourism students of the 'smart tourism destination' concept: a total of 287 of the respondents $(70,52 \%)$ declares to 'know it' or 'having heard about it'. The most associated terms to this concept, even if it's unknown to a certain part of the sample, are: 'technology' or 'technological' (356 counts), 'innovation' or 'innovator' (196), 'personalised' or 'personalisation' (78), 'sustainability' or 'sustainable' (72), 'internet' (42), 'information' (42), 'novelty' or 'novel' (22), 'smart city' (20) or 'smartphone' (18). This indicates that students correctly associate this concept with some other related ones and are conscious of this trend within tourism research and planning. However, a clear gap has been detected between the expectations of tourism students regarding the future importance of ICTs and their recognition of emergent concepts such as the STD, and their formation in these matters, which they qualify as bad.

\subsection{ICT courses in the Spanish tourism curricula}

The content analysis reveals several critical facts in relation to the inclusion of ICT courses in the public Spanish tourism curricula (see table 2). First, there is a notable lack of courses devoted to 'smartness', as only one university offered a course which could be classified in this category. Second, the most usual courses within ICT formation are dedicated to informatics applied to the management of businesses and operations, and in a lesser degree, to destinations. These courses (category 'informatics') are generalist in content and usually focus on basic office software. General courses about information technologies (category 'ICTs') also occupy a significant space in the curriculum together with the data analysis courses, which develop the skills to explode information sources for tourism to inform decisions.

Table 2. Inclusion of ICT courses in the Spanish tourism curricula by type

\begin{tabular}{|c|c|c|c|}
\hline $\begin{array}{c}\text { Categories } \\
\text { (types of courses) }\end{array}$ & Keywords & $\begin{array}{l}\text { Frequ } \\
\text { ency }\end{array}$ & $\begin{array}{l}\text { Compulsory } \\
\text { Optional }\end{array}$ \\
\hline Smartness & $\begin{array}{c}\text { 'smart', 'smartness' 'intelligent', 'intelligence', } \\
\text { 'system’* }\end{array}$ & 1 & 1 \\
\hline \multirow{2}{*}{$\begin{array}{l}\text { Digital marketing } \\
\text { and electronic } \\
\text { intermediation }\end{array}$} & \multirow{2}{*}{$\begin{array}{l}\text { 'digital', 'electronic', 'e- ' } \\
\text { 'internet' 'online', 'web' }\end{array}$} & \multirow[b]{2}{*}{9} & 1 \\
\hline & & & 8 \\
\hline \multirow{2}{*}{ Social Media } & \multirow{2}{*}{$\begin{array}{l}\text { 'social media', 'social network, '2.0', } \\
\text { 'networks' }\end{array}$} & \multirow{2}{*}{3} & 1 \\
\hline & & & 2 \\
\hline \multirow[b]{2}{*}{ ICTs } & \multirow{2}{*}{$\begin{array}{l}\text { 'ICTs', 'Information and Communication } \\
\text { technologies', 'Information and } \\
\text { Communication technology', 'Technology', } \\
\text { 'Technological', 'Technologies', 'new } \\
\text { technologies', 'information'** }\end{array}$} & \multirow[b]{2}{*}{26} & 19 \\
\hline & & & 7 \\
\hline \multirow[t]{2}{*}{ Informatics } & \multirow{2}{*}{$\begin{array}{c}\text { 'Informatics', 'office' } \\
\text { 'software', 'computerised', 'computer', } \\
\text { 'programme', 'processor' }\end{array}$} & \multirow{2}{*}{36} & 28 \\
\hline & & & 8 \\
\hline
\end{tabular}




\begin{tabular}{|c|c|c|c|}
\hline $\begin{array}{c}\text { Data Analysis } \\
\text { and Big data }\end{array}$ & $\begin{array}{c}\text { 'database' 'big data', 'data', 'analytics', } \\
\text { 'information'*, 'system'*, 'Information system' }\end{array}$ & 25 & 15 \\
\hline $\begin{array}{c}\text { Geographic } \\
\text { systems }\end{array}$ & $\begin{array}{c}\text { 'GIS', 'Geographic information systems', } \\
\text { 'system'*, 'Remote sensing' } \\
\text { '"GPS', 'geo' }\end{array}$ & 9 & 10 \\
\hline GDS & 'GDS', 'global distribution systems' & 5 & 7 \\
\cline { 4 - 4 } & & 5
\end{tabular}

*System and **Information keywords were included in two categories (ambiguous meaning) and the final classification of the course was based on the review of the course content.

Many relevant formation requirements for the management of future smart destinations are lagging behind: few efforts are dedicated to social media, digital marketing or geographic information systems, and, more importantly, no specific courses are dedicated to 'smartness' in tourism and destinations, which could elaborate on intelligent systems, real time or data-based decision making. Apart from the limited existence of courses dedicated to GIS, digital marketing and social media, most of them are optional, while formation in basic informatics is usually compulsory (77,78\% of times). The results of the content analysis are in concordance with the answers obtained through the questionnaire, as the bigger offer in 'informatics' and general 'ICTs' courses is matched with a better position of the text processing and database management within the assessment of the students. More advanced technologies do not have almost any space in the tourism curricula and limit the preparation of these students for the smartness era.

Hence, according to these findings, and answering the research question, current tourism higher education isn't preparing future managers of smart destinations properly from a theoretical and applied perspective, at least in Spain.

\section{Discussion and conclusions}

Smart destinations have emerged as a new approach to managing destinations according to the fundamental shift cutting-edge ICTs have meant for all the stakeholders (Gretzel, Reino, et al., 2015; Gretzel, Werthner et al., 2015). Countries like Spain are dedicating huge efforts and funds to develop and try to implement the philosophy of smartness in tourism. At the same time, ICTs are changing the way we understand curricula and disciplines, breaking the 'rules' until now stablished as they transform society and culture (Dredge, Airey, \& Gross, 2015a).

The findings have revealed a gap between the relevance of ICTs for tourism and the evolution towards smartness of destinations, which the own students recognise, and the precarious position the formation on technology occupies in the Spanish curricula. Several key insights are provided by the results of the Spanish case:

- Tourism students believe ICTs will be the biggest driver of change in tourism in the forthcoming years

- Students recognise the concept of STDs and adequately relate several other concepts to it

- They perceive they aren't receiving an appropriate formation in ICTs, in general, and in all the established requirements necessary for facing the smart destination approach as future managers 
- The inclusion of ICT courses in the Spanish tourism curricula is minimal

- Most these ICT courses are outdated and based on overcome tools and concepts

- No specific effort has been made to approach the advent of smartness in tourism and smart destinations. Education does not prepare students for this shift

- No progress has been made in the tourism curriculum design over the last years to cope with the latest advancements of ICTs and their impact over tourism

On another front, the content analysis has revealed an implicit lack of addressing technologies from a wider perspective, which situates the results within the broader debate around educational needs in tourism. Tourism education is becoming more and more complex in response to the challenges the world faces, and the design of curriculum allows to adapt to these evolving needs of the societies to which graduates can contribute with their work (Dredge et al., 2012).

Therefore, acknowledging the prominent role ICTs are taking in current societies and economies and according to the findings posed here, more space should be dedicated in curricula to technological practical skills. This could be articulated through complementary education both in curricular and extra-curricular space: short courses, technology-based, applied and flexible topics and skills applied to real situations (Benckendorff \& Moscardo, 2015). Our findings also implicate a clear need for reorienting this tourism-ICT relationship in the Spanish curriculum towards a more critical approach. Technologies need to be taught both from a practical perspective (which in the case of Spain is clearly lacking), but also from a reflective standpoint. As part of the 'Philosophical practitioner' for which he advocates for, Tribe (2002) believes tourism students not only need to develop practical skills but also a critical view and action towards the effects of tourism on societies and spaces in which it is embedded. This is even more paramount in the case of ICTs, which are capable of breaking time and space barriers, but can also generate potential threats to the way societies have traditionally organised social and economic life. Technologies aren't ideology or consequence free, and education needs to recognise it.

We need to rethink formation constantly to build future professionals and citizens who are critical, creative, innovative but also problem-solving and practical (Dredge et al., 2015a). In this regard, Munar \& Bødker (2015) argue that a different approach towards complex realities like technology and tourism could be taught breaking the traditional constraints of disciplines and embracing innovative perspectives. Listening to the needs expressed by students and their view on their undergoing formation, as done in this research, introduces a novel way of reorienting studies. Thus, grounded on the results, we advocate for a reconstruction of the education in tourism and ICTs in Spain and in other countries that may face with the same problematic. Some good practices detected during the content analysis can serve as inspiration. For instance, the University of Málaga has created the first official master in Tourism and ICTs, and the University of Girona is including many innovative and ICT courses in its programmes. Using the umbrella of 'smart tourism' and the 'smart destination', education designers should canalise this change and include in tourism curriculum a new way of seeing the relationship between technology and tourism.

Acknowledgements This research has been carried out within the project "New approaches for tourism destinations planning and management: conceptualization, case 
studies and problems. Definition of smart tourism destinations models" (CSO2014-59193-R) under the Spanish R\&D\&I Plan financed by the Ministry of Economy and Competitiveness.

\section{References}

Airey, D., Dredge, D., \& Gross, M. J. (2015). Tourism, hospitality and events education in an age of change. In D. Airey, D. Dredge, \& M. J. Gross (Eds.), The Routledge Handbook of Tourism and Hospitality Education (pp. 3-14). Abingdon: Routledge.

Airey, D., \& Tribe, J. (Eds.). (2005). An international Handbook of Tourism Education. Abingdon: Routledge.

Barron, P., Maxwell, G., Broadbridge, A., \& Ogden, S. (2007). Careers in hospitality management: Generation Y's experiences and perceptions. Journal of Hospitality and Tourism Management, 14(2), 119-128. https://doi.org/10.1375/jhtm.14.2.119

Benckendorff, P., \& Moscardo, G. (2015). Generation Y and the curriculum space. In D. Dredge, D. Airey, \& M. J. Gross (Eds.), The Routledge Handbook of Tourism and Hospitality Education (pp. 422-439). Abingdon: Routledge.

Boes, K., Buhalis, D., \& Inversini, A. (2016). Smart tourism destinations: ecosystems for tourism destination competitiveness. International Journal of Tourism Cities, 2(2). https://doi.org/10.1108/IJTC-12-2015-0032

Buhalis, D. (1998). Information technologies in tourism: Implications for the tourism curriculum. In B. D., T. A.M., \& J. J. (Eds.), Information and Communication Technologies in Tourism 1998 (pp. 289-297). Vienna: Springer.

Buhalis, D., \& Amaranggana, A. (2014). Smart tourism destinations. In Z. Xiang \& I. Tussyadiah (Eds.), Information and Communication Technologies in Tourism 2014 (pp. 553-564). Cham: Springer. https://doi.org/10.1007/978-3-319-03973-2

Buhalis, D., \& Law, R. (2008). Progress in information technology and tourism management: 20 years on and 10 years after the Internet-The state of eTourism research. Tourism Management, 29(4), 609-623. https://doi.org/10.1016/j.tourman.2008.01.005

Cantoni, L., Kalbaska, N., \& Inversini, A. (2009). E-learning in tourism and hospitality: A map. Journal of Hospitality, Leisure, Sports and Tourism Education, 8(2), 148-156. https://doi.org/10.3794/johlste.82.263

Choe, Y., \& Fesenmaier, D. R. (2017). The Quantified Traveler: Implications for Smart Tourism Development. In Z. Xiang \& D. R. Fesenmaier (Eds.), Analytics in Smart Tourism Design (pp. 65-77). Switzerland: Springer.

Del Chiappa, G., \& Baggio, R. (2015). Knowledge transfer in smart tourism destinations: Analyzing the effects of a network structure. Journal of Destination Marketing \& Management, 30(10), 1757-1771. https://doi.org/10.1016/j.jdmm.2015.02.001

Dredge, D., Airey, D., \& Gross, M. J. (2015a). Creating the future. Tourism, hospitality and events education in a post-industrial, post-disciplinary world. In D. Dredge, D. Airey, \& M. J. Gross (Eds.), The Routledge Handbook of Tourism and Hospitality Education (pp. 535-550). Abingdon: Routledge.

Dredge, D., Airey, D., \& Gross, M. J. (Eds.). (2015b). The Routledge Handbook of Tourism and Hospitality Education. Abingdon: Routledge.

Dredge, D., Benckendorff, P., Day, M., Gross, M. J., Walo, M., Weeks, P., \& Whitelaw, P. (2012). The philosophic practitioner and the curriculum space. Annals of Tourism Research, $39(4)$,

2154-2176. https://doi.org/http://dx.doi.org/10.1016/j.annals.2012.07.017

Gretzel, U., Reino, S., Kopera, S., \& Koo, C. (2015). Smart Tourism Challenges. Journal of Tourism, 16(1), 41-47. https://doi.org/10.1108/JTF-12-2014-0023

Gretzel, U., Sigala, M., Xiang, Z., \& Koo, C. (2015). Smart tourism: foundations and developments. Electronic Markets, 25(3), 179-188. https://doi.org/10.1007/s12525-0150196-8

Gretzel, U., Werthner, H., Koo, C., \& Lamsfus, C. (2015). Conceptual foundations for understanding smart tourism ecosystems. Computers in Human Behavior, 50, 558-563. 
https://doi.org/10.1016/j.chb.2015.03.043

Ivars, J. A., Celdrán, M. A., Mazón, J., \& Perles, Á. (2017). Towards an ICT Roadmap for Smart Tourism Destinations Based on Prospective Analysis. E-Review of Tourism Research, 8, 1-5.

Jiang, B., \& Tribe, J. (2009). "Tourism jobs-short lived professions": Student attitudes towards tourism careers in China. Journal of Hospitality, Leisure, Sports and Tourism Education, 8(1), 4. https://doi.org/10.3794/johlste.81.168

Jovicic, D. Z. (2017). From the traditional understanding of tourism destination to the smart tourism destination. Current Issues in Tourism. https://doi.org/10.1080/13683500.2017.1313203

Koo, C., Park, J., \& Lee, J.-N. (2017). Smart tourism: Traveler, business, and organizational perspectives. Information \& Management, In press, Editorial. https://doi.org/10.1016/j.im.2017.04.005

Koo, C., Yoo, K.-H., Lee, J.-N., \& Zanker, M. (2016). Special section on generative smart tourism systems and management: Man-machine interaction. International Journal of Information Management, 36(6), 1301-1305. https://doi.org/10.1016/j.ijinfomgt.2016.05.015

Leung, D., Law, R., van Hoof, H., \& Buhalis, D. (2013). Social Media in Tourism and Hospitality: A Literature Review. Journal of Travel \& Tourism Marketing, 30(1-2), 322. https://doi.org/10.1080/10548408.2013.750919

Majó, J. (2004). Las Tecnologías de la Información y las Comunicaciones en el Currículum de los Estudios de Turismo. In V Congreso "Turismo y Tecnologías de la Información y las Comunicaciones” TuriTec (pp. 303-325). Málaga: Universidad de Málaga.

Medina, S., \& González, R. (2010). LA FORMACIÓN EN TECNOLOGÍAS DE LA INFORMACIÓN Y DE LAS COMUNICACIONES (TIC) EN LA TITULACIÓN DE TURISMO:¿ ES ADECUADA? Teoría de La Educación. Educación Y Cultura En La Sociedad de La Información, 11(3), 371-388.

Ministerio de Industria, E. y T. (2013). Plan Nacional e Integral de Turismo 2012-2015. Retrieved from http://www.tourspain.es/es-es/VDE/Documentos Vision Destino Espaa/Plan Nacional e Integral de Turismo 2012_2015_FINAL_REVISADO 150313.pdf

Morais, E. P., Cunha, C. R., \& Gomes, J. P. (2013). The information and communication technologies in tourism degree courses: the reality of Portugal and Spain. Journal of ELearning and Higher Education, 2013. https://doi.org/10.5171/2013. 611948

Munar, A. M., \& Bødker, M. (2015). Information technologies and tourism. The critical turn in curriculum development. In D. Airey, D. Dredge, \& M. J. Gross (Eds.), The Routledge Handbook of Tourism and Hospitality Education (pp. 105-117). Abingdon: Routledge.

Neuhofer, B., Buhalis, D., \& Ladkin, A. (2015). Smart technologies for personalized experiences: a case study in the hospitality domain. Electronic Markets, 25, 243-254. https://doi.org/10.1007/s12525-015-0182-1

Richardson, S. (2009). Undergraduates' perceptions of tourism and hospitality as a career choice. International Journal of Hospitality Management, 28(3), 382-388. https://doi.org/doi:10.1016/j.ijhm.2008.10.006

Richardson, S., \& Thomas, N. J. (2012). Utilising generation Y: United States hospitality and tourism students' perceptions of careers in the industry. Journal of Hospitality and Tourism Management, 19, e10. https://doi.org/doi 10.1017/jht.2012.1

SEGITTUR. (2015). Informe destinos turísticos inteligentes: construyendo el futuro. Retrieved fromhttp://www.segittur.es/opencms/export/sites/segitur/.content/galerias/descargas/proy ectos/Libro-Blanco-Destinos-Tursticos-Inteligentes-construyendo-el-futuro.pdf

Sheldon, P., Fesenmaier, D., Woeber, K., Cooper, C., \& Antonioli, M. (2008). Tourism Education Futures, 2010-2030: Building the Capacity to Lead. Journal of Teaching in Travel \& Tourism, 7(3), 61-68. https://doi.org/10.1080/15313220801909445

Sigala, M., \& Baum, T. (2003). Trends and issues in tourism and hospitality higher education: Visioning the future. Tourism and Hospitality Research, 4(4), 367-376.

Tribe, J. (2002). The philosophic practitioner. Annals of Tourism Research, 29(2), 338-357 
Vera, J. F., \& Ivars, J. A. (2001). La formación y la investigación turística en España: una visión de síntesis. Papers de Turisme, 29, 7-27.

Wang, D., Li, X. R., \& Li, Y. (2013). China's "smart tourism destination" initiative: A taste of the service-dominant logic. Journal of Destination Marketing \& Management, 2(2), 5961. https://doi.org/10.1016/j.jdmm.2013.05.004

Wang, D., Park, S., \& Fesenmaier, D. R. (2012). The Role of Smartphones in Mediating the Touristic Experience. Journal of Travel Research, 51(4), 371-387. https://doi.org/10.1177/0047287511426341

Wang, X., Li, X. R., Zhen, F., \& Zhang, J. (2016). How smart is your tourist attraction?: Measuring tourist preferences of smart tourism attractions via a FCEM-AHP and IPA approach. Tourism Management,

54 , 309-320. https://doi.org/10.1016/j.tourman.2015.12.003

Xiang, Z., \& Fesenmaier, D. R. (2017). Big Data Analytics, Tourism Design and Smart Tourism. In Z. Xiang \& D. R. Fesenmaier (Eds.), Analytics in Smart Tourism Design (pp. 299-307). Switzerland: Springer. 